\title{
Value Relevance of Accounting Information in the Botswana Listed Companies
}

\author{
Christian J. Mbekomize ${ }^{1} \&$ Selinkie Popo ${ }^{1}$ \\ ${ }^{1}$ Faculty of Business, University of Botswana, Gaborone, Botswana \\ Correspondence: Christian J. Mbekomize, Faculty of Business, University of Botswana, Private Bag UB 00701, \\ Gaborone, Botswana.
}

Received: March 20, 2020

Accepted: April 9, $2020 \quad$ Online Published: April 22, 2020

doi:10.5539/ibr.v13n5p46

URL: https://doi.org/10.5539/ibr.v13n5p46

\begin{abstract}
The main purpose of the study was to examine the statistical relationship between four sets of accounting information and market share prices using the data of companies listed on the Botswana Stock Exchange over the period from 2012 to 2018. Annual reports and Botswana Stock Exchange - Equity Statistics data bank were the sources of accounting information and market prices respectively. The Ordinary Least Square regression method was used to analyse data. The results suggest that earnings are the most value relevant information to share prices followed by dividends and lastly book value. While book value yielded weak value relevance operating cash flows did not explain changes in share prices in the Botswana equity market. The combination of earnings and dividends was more value relevant than any other mix of accounting amounts. The study further revealed that the market share price at the end of the 6th month from the year end was the most influenced price. These results have implications to quoted companies regarding the importance they attach on earnings and dividends information and their timely publication. The paper recommends for speedy dissemination of earnings and dividends information since investors significantly consider such information in market share pricing decisions.
\end{abstract}

Keywords: value relevance, earnings, dividends, book value, cash flows, Botswana

\section{Introduction}

\subsection{Background Information}

Financial reporting is concerned with the dissemination of useful information to financial statements users to assist them to make various informed decisions. According to accounting standards setters worldwide in order for the information to be useful to users it must bear two key qualitative characteristics of relevance and reliability. It is worth mentioning that in recent conceptual frameworks of financial reporting, particularly those of Financial Accounting Standards Board (2010) and International Accounting Standards Board (2018), the attribute of reliability has been replaced by the characteristic of faithful representation (BrainMass, n.d). The attribute of relevance refers to information being capable in making a difference in the decisions made by users. In addition, information capable of making a difference in decisions must have a predictive value (should be able to predict future outcomes) and/or must have confirmatory value (should be able to provide feedback on the previous evaluations (Financial Accounting Standards Board, 2010; International Accounting Standards Board, 2018). Alexander, Britton and Jorissen (2007) add that to be relevant the information must resonate with why the user needed that information in the first place. The information that does not satisfy the users' interests is irrelevant to them.

The characteristic of faithful representation refers to the reported information being capable of displaying the substance it intended to provide. Moreover, faithfully presented information is considered to be complete, neutral and error free and is affected by the level of uncertainty with which it was determined. The reported information is telling the true story of what actually transpired and therefore can be trusted by users. The usefulness of information is said to be boosted by the characteristics of comparability, verifiability, timeliness and understandability (Financial Accounting Standards Board, 2018). The quality of comparability implies that the user would find the reported information useful if the user can identify similarities or differences among similar items reported by different entities or provided by the same entity in different reporting periods. The quality of verifiability is whereby different knowledgeable and independent users would arrive at the same conclusion that 
the reported information is faithfully depicting what it purported to depict (Financial Accounting Standards Board, 2010; International Accounting Standards Board, 2018). The characteristic of timeliness refers to making the information available to users on time to influence their decisions. Understandability means that the manner the information is reported should consider the ability and knowledge of users in comprehending it (Alexander, Britton \& Jorissen, 2007).

It is a commonly accepted view among researchers and accounting standards setters that general purpose financial statements are primarily prepared for existing and potential investors who make decisions involving buying, selling or holding shares of the reporting entity (Financial Accounting Standards Board, 2010; Olugbenga \& Atanda, 2014). Barth, Beaver and Landsman (2001) assert that a primary focus of financial statements is to assist shareholders in their equity investment decisions. Holthausen and Watts (2001) note that most authors assume that accounting's dominant role is to provide information relevant to equity valuation. Due to the perceived nexus between investors, their requirement of relevant information and the resultant capital markets sustenance, the accounting research has increasingly concentrated on investigating the value relevance of accounting information. The key question has been whether the accounting information disclosed in the financial statements incorporates the information that investors can consider value relevant for their decisions to predict the value of the reporting entity.

Since the seminal work of Ball and Brown (1968) which focused on the relevance and timeliness of reported earnings on share prices (Ball and Brown, 2014) accounting researchers have dedicated themselves on establishing the relationship between the changes in share prices or returns and the changes in the accounting amounts. Several issues have emerged from prior studies on relevance of accounting information such as which accounting information has more predictive power of market share price than others (Badu \& Appiah,2018; Kwon, 2009; Akeem Adetunji, 2016); changes in the value relevance of accounting information- whether it is declining or increasing (Barth, Li and McClure, 2018; Badu \& Appiah 2018); the significance of value relevance studies to accounting setters (Holthausen \&Watts, 2001; Barth, Beaver \& Landsman, 2001); and the value relevance of other information, for instance reports on corporate social responsibility (de Klerk \& de Villiers, 2012), to mention just a few.

According to Barth, Beaver and Landsman (2001) an accounting amount would be described as value relevant if it has a predicted association with share market values. The authors elaborate that the key commonality in various definitions of value relevance is that an accounting amount is deemed value relevant if it has a significant association with equity market value. Akeem Adetunji (2016) views value relevance implying the degree of statistical relationship between information included in accounting statements and market value of shares or returns. In other words, the reported accounting amount, for example earnings or book value that is proved to provide more information to investors to consider in arriving at market value of shares is believed to be value relevant. Barth (2000) points out that the information that help the investors to assess the value of the firm for the purpose of making informed investment choices is value relevant. Barth, Beaver and Landsman (2001) distinguish value relevant from decision relevant in that information can be value relevant but not be decision relevant if it is superseded by more timely information. The value relevant information influences valuation of a share and what is decision relevant influences what alternative course of action to take. The current study seeks to establish the statistical link between the earnings, book value, dividends and operating cash flows per share and share prices using the financial statements of companies listed in the Botswana Stock Exchange.

\subsection{Botswana Stock Exchange Background}

Botswana stock exchange (BSE) formally began trading in 1989 as the Botswana Share Market and it was later promulgated by Act of parliament in 1994. Its main mandate is to operate and regulate the equities and fixed interest securities market. The BSE commenced with 5 listed companies and one stock broker. It has now grown to 37 entities made up of domestics companies and dual listed foreign companies. At the time of the current study in mid-2019, BSE had 4 brokers and 4 primary dealers who were allowed to trade in government and corporate bonds which stood at 33 in number. From a single index known as Botswana Share Market index (BSI) in 1989 BSE has grown into 3 indices namely: Botswana Domestic Companies Index (DCI), Foreign Companies Index (FCI) and the All Company index (ACI). The Botswana Domestic Companies Index is the main index used to gauge the performance of the exchange. As a result of market diversification stemming from consistent growth of the Botswana economy, the composition of BSE at the time of the study was categorised into nine industrial sectors: Wholesaling and Retailing, Financial Services and insurance, Banking, Property and Property trust, Mining, Security services, Transport and Tourism, Energy, and Health care and Emergency services. The BSE boasts of its phenomenon growth from initial market capitalisation of 225 million pula in 1989 to 413,168.3 
million pula at the end of 2018. The BSE is one of Africa's best performing stock exchanges, averaging $24 \%$ aggregate return in the past decade (Botswana Stock Exchange, n.d.). This has allowed the BSE to be the third largest stock exchange in terms of market capitalization, in Southern Africa behind the Johannesburg Stock Exchange and the Namibian Stock Exchange. The BSE has contributed significantly to the national economy as it plays a critical role of providing the platform on which government; state-owned entities and the private sector can raise debt and equity capital (Botswana Stock Exchange, n.d).

The application of International Financial Reporting Standards (IFRS) in preparing financial statements in Botswana was given a legal mandate by Companies Act of 2003 which required all public companies and non-exempt companies to use IFRS. Non-exempt companies are private companies that are above a specified threshold of turnover and total assets for mandatory audit. In Botswana the authority to adopt, issue and update financial reporting standards for public interest entities and ensuring that they are consistent with IFRS is vested upon the Botswana Accountancy Oversight Authority (BAOA) which was established by the Financial Reporting Act of 2010. At time of this study the BAOA had adopted IFRS issued by IASB and therefore all BSE listed companies as part of Public Interest Entities (PIEs) applied the IFRS in wholesome. It is mandatory for all Companies listed with BSE to release their interim and abridged audited financial statements within 3 months of their production (Botswana Stock Exchange, 2018).

\subsection{Problem Statement}

Numerous studies have been conducted to investigate the relationship between accounting information disseminated through the financial statements and the market share price. However, the available literature is still not conclusive on the questions of which financial variable is more predictive of the market share value than the others (Barth, Li and McClure, 2018; Badu \& Appiah 2018); and which share price mostly reflects investors' consideration of accounting information (Jabar, 2012). Moreover, most of the value relevance research emanates from the developed world such as America and Europe although a growing number of such studies can be traced in the two big economies of Africa, Nigeria and South Africa. See for example, Ernest and Oscar (2014); Olugbenga and Atanda (2014) and Busari and Bagudo, (2018) in Nigeria; and Baboukardos and Rimmel (2016), Venter, Emanuel, and Cahan (2014), and de Klerk and de Villiers (2012) in South Africa. Knowledge about how and when the investors respond to the accounting information announcements is vital for the development of capital markets whose growth is pivotal to the economic survival of any country. It is therefore appropriate to extend the literature about value relevance of financial information on the share prices by examining variables from developing countries' sources. This study contributes to the extant literature by focusing on four independent financial variables namely earnings per share, book value per share, dividends per share, and operating cash flows per share. The study also compares the effect of the four independent variables on the market share price as at 3 different dates: at year end date, 3 months after year end date and 6 months after year end date.

\subsection{Objectives}

The general objective of this study is to examine the relationship between accounting information and market share values using the data of companies listed on the Botswana Stock Exchange over the period of seven years from 2012 to 2018. Specifically the study has the following objectives:

1. To establish the relationship between market share prices at the end of the year with earnings, book value, dividends and cash flows per share.

2. To establish the relationship between market share prices 3 months after year end with earnings, book value, dividends and cash flows per share.

3. To establish the relationship between market share prices 6 months after year end with earnings, book value, dividends and cash flows per share.

4. To determine the share price that mostly reflects the investors' consideration of accounting information.

\section{Literature Review}

\subsection{Theoretical Review}

This study is hinged on the market share valuation model initially developed by Ohlson (1995). The model represents firm value as a linear function of book value of equity and the present value of expected future abnormal earnings (Barth, Beaver \& Landsman, 2001; de Klerk \& de Villiers, 2012; Kumari \& Mishra, 2017). The model advocates that investors should pay more than the book value of equity for the share if the present value of expected earnings is higher than the book value or should pay less if the expected earnings are less than 
anticipated. Applied in this sense the model is used to forecast the share value of a firm. Barth, Beaver and Landsman (2001) however expound further that with additional assumptions of linear information dynamics, firm value can be re-expressed as a linear function of equity book value, net income, dividends, and other information. Used in this manner the model is useful in determining the association between share prices and accounting information in an attempt to establish the explanatory power of accounting figures to share prices. Net income and book value as reflected in the income statement and statement of financial position respectively have always been considered the prominent factors in explaining the change in the market share price of an entity (Barth, Li \& McClure, 2018; Karğın, 2013; Ali \& Hwang, 2000). A variety of prior studies have employed the Ohlson's model to examine the value relevance of accounting information while focusing on earnings and book value. See for example, Badu and Appiah (2018), Akeem Adetunji (2016), Enofe, Asiriuwa and Ashafoke (2014) and Karğın, 2013, just to mention a few.

In its extended version Ohlson's model has been used to examine the statistical association between market share prices and various accounting numbers beyond earnings and book value. For example Elshandidy (2014) added ownership structure on earnings and book value; Ernest and Oscar (2014) added leverage, Jabar (2012) added cash flows and Busari and Bagudo (2018) and Olugbenga and Atanda (2014) added dividends and cash flows.

From the review of value relevance literature Holthausen and Watts (2001) identified 3 categories of studies that adopt association approach in analysing value relevance of accounting numbers namely, relative association, incremental association and marginal information content. Relative association refers to studies that compare the effect of accounting amounts on market share value under different accounting standards regimes. Incremental association refers to studies that examine whether the accounting number of interest explains better the share value or returns than others. They focus on analysing the explanatory power of an accounting number. The marginal information content studies concentrate on analysing whether a disclosure of particular accounting information would add to the information that the investor already has (Olugbenga \& Atanda, 2014).

This study takes an incremental approach in examining the linear relationship between market share price on one side and earnings, book value, operating cash flows and dividends per share on the other side.

\subsection{Empirical Literature Review}

The empirical literature review below is organized according to the two main focal points of this study. First, the study seeks to establish which of the four sets of accounting information that have been relatively extensively investigated in prior studies has the highest predictive power of the market share value. Therefore, the studies that use earnings, dividends, book value and operating cash flows per share as independent variables, in various combinations, with a focus on the emerging economies were reviewed. Second, the current study aims to establish the share price that mostly reflects investors' usage of the released accounting information in making investment decisions. Hence, the studies that use market share price at different dates in a year as dependent variable were referred to.

\subsubsection{Value Relevance of Accounting Information}

Accounting research investigating the value relevance of accounting amounts has embraced a variety of approaches. While the focal point, being the market share value, has remained the same, the independent and control variables have been expanded from traditional internal accounting information namely earnings and book value to external factors such as rise in technology, improvement of accounting standards and country specific factors such as economic, social, political and legal components (Barth, Li \& McClure, 2018; Karğın, 2013; Ali \& Hwang, 2000). Che (2007) investigated the value relevance of accounting information and the relationship between market share prices and different types of shareholding in the context of China and established a strong association between accounting information as reflected in the statement of comprehensive income and statement of financial position.

Kwon (2009) investigated the value relevance of accounting information in Korean companies with a view of answering five questions. Among them were the questions about the most value relevant variable among book value, earnings and cash flows in normal situations, in instances of earning management and/or situations of negative earnings. Other questions related to whether value relevance of the 3 variables has been increasing or declining; and whether cash flow can replace earnings. The author used the share price at the end of 3 months after the year end as dependent variable and book value, earnings and cash flows were the independent variables. The study established that book value is the most value relevant variable and cash flows have more value relevance than earnings. Furthermore, the results suggested that combined value relevance of book value and cash flows is more value relevant than that of book value and earnings, implying that cash flows can be a substitute for earnings in equity valuation model. 
Busari and Bagudo (2018) investigated the comparative value relevance of financial information for consolidated and separated financial statements of financial institutions. They used earnings per share, book value per share, dividends per share and cash flows per share as independent variables. They observed that on the overall, accounting information on both consolidated and separated financial information were value relevant although the consolidated information was more value relevant than the separated financial information.

Ernest and Oscar (2014) conducted a study to compare value relevance of earnings, book value and leverage per share in banking and petroleum sectors in Nigeria. They established that earnings per share were the most considered by investors in share price decisions and information in the petroleum sector was more relevant than that of the banking sector.

The study by Olugbenga and Atanda (2014) examined the value relevance of accounting information focusing on earnings, book value, cash flows and dividends as independent variables. They reported that overall the accounting information of listed companies in Nigeria was value relevant but did not follow a disernable pattern over the period from 1990 to 1999 . The authors noted that the value relevance was weak in the periods of the country's political crisis and global economic turmoil.

The study by Agostino, Drago and Silipo (2011) in the European banking industry revealed that the adoption of IFRS enhanced the value relevance of earnings and book value of transparent banks but not of less transparent banks. Karğın (2013) also examined the effect of adoption of IFRS on value relevance of earnings and book value in Turkey. The study reported the improvement of value relevance of book value after the introduction of IFRS but not of earnings.

Sami and Zhou (2004) compared the value relevance of accounting information from Chinese GAAP compliant market with that of International Accounting Standards compliant market. They reported value relevance in both markets and a higher value relevance of accounting information produced by IAS compliant companies. Elshandidy (2014) using the data from 3 stock markets in China also examined the value relevance of the accounting information prepared using different sources of accounting standards aplicable in China namely, Chinese Accounting Standards for domestic firms; International Financial Reporting Standards (IFRS) for both domestic and overseas firms; and Hong Kong GAAP for Hong Kong and overseas firms. Elshandidy used two dependent variables namely, closing share price and market value measured as share price multiplied by number of shares in issue. The independent variables were the earnings per share and book value per share with a control variable of ownership structure. The study revealed that accounting information was value relevant in the companies using Chinese standards and those using IFRS, while the information produced by companies following Hong Kong GAAP was partially relevant. The study also revealed that the convergence of Chinese Accounting Standards with IFRS produced more value relevant information.

Ali and Hwang, (2000) carried out a study in 16 non-US countries to examine the country-specific factors influencing value relevance of accounting information. They observed that value relevance was lower for countries with bank oriented financial systems; value relevance was lower in countries where the private sector bodies do not participate in standard setting process; value relevance was lower in continental model countries as compared to British -American model countries; and value relevance was lower where taxation rules play a key role in financial accounting measurements. Ali and Hwang further noted that value relevance was higher in companies committing more resources for external auditing services. These results imply that different systems adopted by a country will have a bearing on the value relevance of the information produced by reporting entities in that country.

Akeem Adetunji (2016) investigated the association between accounting numbers and market values of listed Deposit Money Banks in Nigeria and found out that the accounting information of sampled banks was value relevant for share valuation although the earnings information appeared to be irrelevant.

Enofe, Asiriuwa and Ashafoke (2014) examined the value relevance of earnings per share and book value per share on the average share prices of listed banks in Nigeria and observed that accounting information has the ability to capture information that affects equity value and there is a relationship between accounting numbers and share prices. These results were supported by Olowolaju and Ogunsan (2016) who investigated the value relevance of accounting information in the Deposit Money banks utilizing earnings per share, book value per share and dividend per share. The study found out that book value per share and dividends per share had a significant relationship with the share price at 5\% significant level. Also the study revealed that earnings per share have ability to predict the share price. On the contrary, the work by Umoren, Akpan and Ekeria (2018) that investigated the value relevance of accounting information published by financial institutions in Nigeria focusing on earnings per share and book value per share, revealed no significant relationship between both independent 
variables and share price. Earlier on, the work by Okafor and Odia (2011) had also indicated that earnings per share in the Nigerian Banking Sector did not have significant impact on the share price despite the strong association among the two variables.

Mixed results about the value relevance of specific accounting figures are evidenced in the above literature confirming the need to investigate the phenomenon further. The above literature seems to suggest that value relevance of accounting information is affected by a variety of factors such as industry in which the company operates and accounting standards applied.

\subsubsection{Value Relevance and Share Price Date}

While most prior studies have used the year end market share value as a dependent variable few studies have attempted to focus on different dates. Uwuigbe et al. (2016) examined the effects of value relevance of financial statements on firms' share price in Nigeria and reported that a significant positive relationship existed between earnings per share (EPS) and year end share price.

Jabar (2012) examined the influence of institutional factors on the value relevance of accounting information in the context of Jordan with a view of establishing which share price proxy is more reliable in indicating value relevance. Jabar used average annual share price, annual closing share price and share price after a 3 months period following the financial year-end as the dependent variables. The author divided the independent variables into two groups: accounting information comprising earnings, book value and cash flows and internal factors consisting of foreign ownership, trading volume, and financial disclosure time, and financial disclosure level, number of shareholders, listing status, company's age and type of industry. The study identified book value to possess the greatest value relevance and to be the best predictor of firm value. The work of Jabar also revealed that the value relevance of earnings and book value is higher for companies having foreign ownership, larger trading volume and larger shareholder numbers. In addition, companies that conform to financial disclosure time, that are listed on the main board and that are older in age reflect greater value relevance of earnings and book values. Value relevance of book value was found to be greater for companies complying with disclosure requirements and for services companies. Jabar also established that annual closing share price proxy was more reliable in detecting the value relevance of accounting information.

Agostino, Drago and Silipo (2011) examined the value relevance of IFRS using the share price after 6 months as dependent variable and book value, earnings per share and date of IFRS becoming mandatory as independent variables. They established that the introduction of IFRS enhanced the information content of both earnings and book value for more transparent banks but for less transparent entities only value relevance of earnings per share was improved.

Most value relevant studies have focused on the year end share price as the dependent variable ignoring the fact that the time of releasing the accounting information can also have an impact on the share price. The current study attempts to examine the effect of accounting information on different 3 prices that have been used in value relevant literature.

\subsection{Hypotheses Development}

The above literature provides mixed evidence regarding the value relevance of earnings, book value, dividends and cash flows to market share prices at different points in a year. Depending on when the investors have access to the reported information and therefore are able to consider it in deciding on the share prices, value relevance may change during the year. We therefore hypothesize as follows:

Hypothesis 1: Earnings are value relevant to market share prices at the end of the year.

Hypothesis 2: Earnings are value relevant to market share prices at the end of 3rd month after year end.

Hypothesis 3: Earnings are value relevant to market share prices at the end of 6th month after year end.

Hypothesis 4: Book value is value relevant to market share prices at the end of the year.

Hypothesis 5: Book value is value relevant to market share prices at the end of 3rd month after year end.

Hypothesis 6: Book value is value relevant to market share prices at the end of 6th month after year end.

Hypothesis 7: Dividends are value relevant to market share prices at the end of the year.

Hypothesis 8: Dividends are value relevant to market share prices at the end of 3rd month after year end.

Hypothesis 9: Dividends are value relevant to market share prices at the end of 6th month after year end.

Hypothesis 10: Cash flows are value relevant to market share prices at the end of the year. 
Hypothesis 11: Cash flows are value relevant to market share prices at the end of 3rd month after year end.

Hypothesis 12: Cash flows are value relevant to market share prices at the end of 6th month after year end.

\section{Method}

The target population for this study was the 26 companies listed on the domestic board of the Botswana Stock Exchange. Earnings, dividends, book value and operating cash flows per share were computed from data obtained from the annual reports of 14 companies whose financial statements for the period from 2012 to 2018 could be accessed. Market share prices of the 14 companies were obtained from Botswana Stock Exchange Equity Statistics for period from January 2012 to September 2019. The generated observations totaled 98.

\subsection{Dependent Variables}

The dependent variable for this study is the market share price for each company under study. Prior studies that have employed Ordinary Least Square Regression model to investigate the statistical relationship between accounting amounts and market share value have used different periods' share prices as dependent variable. For example, Uwuigbe et al. (2016) used last day share price and Badu and Appiah (2018) used market price 3 months after the year end. Agostino, Drago and Silipo (2011) used share price 6 months after the end of the year. Enofe, Asiriuwa and Ashafoke (2014) made use of average annual share price. Jabar (2012) used average annual share price, annual closing share price and share price after a 3 month period following the financial year-end and reported that the closing share price was more reliable in reflecting the value relevant information. These studies demonstrated the existence of value relevance of accounting information for market share prices at the end of different periods. The question when do investors exactly incorporate the released accounting information in the share prices is yet to be conclusively answered. Therefore this study aims to contribute to this debate by using the market prices at the end of the year (MSPjt), at end of 3 months after the year end (MSPjt $\left.{ }_{+1 / 4}\right)$ and at end of 6 months after year end ( $\left.\mathrm{MSPjt}_{+1 / 2}\right)$ in an attempt to establish the market price which reflects the accounting information more than the others.

\subsection{Independent Variables}

Consistent to previous studies, for example Hodgson and Stevenson-Clarke (2000), Kwon (2009), Jabari (2012), Busari and Bagudo (2018) and Olugbenga and Atanda(2014) this study used earnings per share, book value per share, cash flows per share and dividends per share as independent variables. Table 1 shows how each independent variable was measured.

Table 1. Measurement of independent variables

\begin{tabular}{lll}
\hline Independent Variables & Abbreviation & Measurements \\
\hline Book value per share & BVS & $\begin{array}{l}\text { Ordinary shareholder's equity divided by weighted average shares in } \\
\text { issue during the year. } \\
\text { Paid and proposed dividends in a year divided by number of shares } \\
\text { ranking for dividends. } \\
\text { Profit for the year attributable to equity holders divided by weighted } \\
\text { average shares in issue during the year. } \\
\text { Net cash generated by or (utilised in) operating activities divided by } \\
\text { weighted average shares in issue during the year. }\end{array}$ \\
\hline
\end{tabular}

\subsection{The Model}

Using the model from previuos studies (see for example, Olugbenga and Atanda, 2014) this study constructed the following 3 main models.

$$
\begin{aligned}
& \text { MSPjt }=\beta_{0}+\beta_{1} \mathrm{EPSjt}+\beta_{2} \mathrm{BVSjt}+\beta_{3} \mathrm{DPSjt}+\beta_{4} \mathrm{CFSjt}+\varepsilon j \mathrm{t} \\
& \mathrm{MSPjt}_{+1 / 4}=\beta_{0}+\beta_{1} \mathrm{EPSjt}+\beta_{2} \mathrm{BVSjt}+\beta_{3} \mathrm{DPSjt}+\beta_{4} \mathrm{CFSjt}+\varepsilon j \mathrm{jt} \\
& \mathrm{MSPjt}_{+1 / 2}=\beta_{0}+\beta_{1} \mathrm{EPSjt}+\beta_{2} \mathrm{BVSjt}+\beta_{3} \mathrm{DPSjt}+\beta_{4} \mathrm{CFSjt}+\varepsilon j \mathrm{t}
\end{aligned}
$$

Where

MSPjt represents the market share price of firm $\mathrm{j}$ at the end of year $\mathrm{t}$,

MSPjt $_{+1 / 4}$ represents the market share price of firm $j$ at end of 3 months after the end of year $t$

$\mathrm{MSPjt}_{+1 / 2}$ represents the market share price of firm $\mathrm{j}$ at end of 6 months after the end of year $\mathrm{t}$ 
$\beta_{0}$ represents the market share price when all independent variables are equal to zero.

$\beta_{1}, \beta_{2}, \beta_{3}, \beta_{4}$, represent the quantified effect that the independent variables have on the market share value.

EPSjt represents earnings per share of firm $j$ at the end of year $t$

BVSjt represents book value per share of firm $j$ at the end of year $t$

DPSjt represents dividends per share of firm $j$ at the end of year $t$

CFSjt represents cash flows per share of firm $j$ at the end of year $t$

In order to determine the explanatory power of each independet variable individually, twelve bivariate models were costructed.

For the market share price at year end the following models were constructed:

$$
\begin{aligned}
& \text { MSPjt }=\beta_{0}+\beta_{1} \text { EPS jt }+\varepsilon j t \\
& \text { MSPjt }=\beta_{0}+\beta_{2} \text { BVS jt }+\varepsilon j t \\
& \text { MSPjt }=\beta_{0}+\beta_{3} \text { DPS jt }+\varepsilon j t \\
& \text { MSPjt }=\beta_{0}+\beta_{4} \text { CFS jt }+\varepsilon j t
\end{aligned}
$$

For the market price at the end of 3 months after the year end, the following models were framed:

$$
\begin{aligned}
& \operatorname{MSPjt}_{+1 / 4}=\beta_{0}+\beta_{1} \text { EPS jt }+\varepsilon j t \\
& \operatorname{MSPjt}_{+1 / 4}=\beta_{0}+\beta_{2} \text { BVS jt }+\varepsilon j t \\
& \operatorname{MSPjt}_{+1 / 4}=\beta_{0}+\beta_{3} \text { DPS jt }+\varepsilon j t \\
& \operatorname{MSPjt}_{+1 / 4}=\beta_{0}+\beta_{4} \text { CFS jt }+\varepsilon j t
\end{aligned}
$$

For the market price at end of 6 months after the year end, the following models were formulated:

$$
\begin{aligned}
\operatorname{MSPjt}_{+1 / 2} & =\beta_{0}+\beta_{1} \text { EPS jt }+\varepsilon j t \\
\text { MSPjt }_{+1 / 2} & =\beta_{0}+\beta_{2} \text { BVS jt }+\varepsilon j t \\
\operatorname{MSPjt}_{+1 / 2} & =\beta_{0}+\beta_{3} \text { DPS jt }+\varepsilon j t \\
\operatorname{MSPjt}_{+1 / 2} & =\beta_{0}+\beta_{4} \text { CFS jt }+\varepsilon j t
\end{aligned}
$$

\section{Results}

In our analysis we computed the descriptive statistics, performed correlations of all the variables and conducted regressions on market price on one hand and accounting amounts on the other.

\subsection{Descriptive Statistics}

Table 2 displays the descriptive statistics which indicate that the market share prices of sampled companies were between 82 thebe and 2870 thebe at the end of the year, between 94 thebe and 2900 at the end of 3 months after the year end and between 82 thebe and 2950 thebe 6 months after year end. The average market price at the end of year was around 651 thebe, and that at the end of 3 months after year end stood at about 669 thebe while that one at the end of 6 months after year end stood at 683 thebe. Overall, there were no major fluctuations among the 3 market share prices. The minimum EPS at the end of the year was negative 63.5 thebe while the maximum stood at 218 thebe with an average of 54 thebe. The minimum DPS was 0 thebe while the maximum was 170 thebe with an average of 38 thebe. At the end of the year the minimum of BVS was 60 thebe and the maximum was 1061 thebe with an average of 278 thebe. The minimum of CFS was a whooping negative 1472 thebe while the maximum was 719 thebe with an average of 28 thebe.

Table 2. Descriptive statistics

\begin{tabular}{lrrrrr}
\hline & $\mathrm{N}$ & Minimum & Maximum & Mean & Std. Deviation \\
MSPjt & 98 & 83 & 2870 & 650.94 & 586.496 \\
\hline MSPjt $_{+1 / 4}$ & 98 & 94 & 2900 & 668.69 & 595.475 \\
MSPjt $_{+1 / 2}$ & 98 & 82 & 2950 & 682.87 & 619.793 \\
EPS & 98 & -63.50 & 218.00 & 54.1127 & 46.60006 \\
DVS & 98 & .00 & 170.00 & 37.5167 & 37.64720 \\
BVS & 98 & 60.26 & 1061.34 & 278.2266 & 230.57695 \\
CFS & 98 & -1472.18 & 718.80 & 28.1408 & 191.27183 \\
\hline
\end{tabular}


Operating cash flows in the sampled companies reflected huge fluctuations implying that a good number of them had subdued cash flows during the period under study. About $28 \%$ of observations examined contained negative operating cash flows.

\subsection{Correlations}

Table 3 presents the correlation matrix of market share price at year end, market share price 3 months after year end, market share price 6 months after year end, earnings per share, dividends per share, book value per share and cash flows per share. There were significant positive and very strong correlations between the three market share prices at end of the year, 3 months after the end of year and 6 months after the end of the year $(r=993 ; r$ $=.983 ; \mathrm{r}=.994$ respectively). This implies that share prices at three different points were moving in the same direction. Table 3 also exhibits a significant positive and strong association between earnings and the 3 market share prices $(r=.743 ; r=.760 ; r=.780$ respectively).

Table 3. Correlations matrix

\begin{tabular}{|c|c|c|c|c|c|c|c|c|}
\hline & & MSPjt & $\mathrm{MSPjt}_{+1 / 4}$ & MSPjt $_{+1 / 2}$ & EPS & DVS & BVS & CFS \\
\hline MSPjt & $\begin{array}{l}\text { Pearson Correlation } \\
\text { Sig. (2-tailed) }\end{array}$ & 1 & & & & & & \\
\hline MSPjt $_{+1 / 4}$ & $\begin{array}{l}\text { Pearson Correlation } \\
\text { Sig. (2-tailed) }\end{array}$ & $\begin{array}{c}.993^{* *} \\
.000\end{array}$ & 1 & & & & & \\
\hline $\mathrm{MSPjt}_{+1 / 2}$ & $\begin{array}{l}\text { Pearson Correlation } \\
\text { Sig. (2-tailed) }\end{array}$ & $\begin{array}{r}.983^{* *} \\
.000\end{array}$ & $\begin{array}{r}.994^{* *} \\
.000\end{array}$ & 1 & & & & \\
\hline EPS & $\begin{array}{l}\text { Pearson Correlation } \\
\text { Sig. (2-tailed) }\end{array}$ & $\begin{array}{r}.743^{* *} \\
.000\end{array}$ & $\begin{array}{r}.760^{* *} \\
.000\end{array}$ & $\begin{array}{c}.780^{* *} \\
.000\end{array}$ & 1 & & & \\
\hline DVS & $\begin{array}{l}\text { Pearson Correlation } \\
\text { Sig. (2-tailed) }\end{array}$ & $\begin{array}{r}.662^{* * *} \\
.000\end{array}$ & $\begin{array}{r}.661^{* * *} \\
.000\end{array}$ & $\begin{array}{r}.660^{* * *} \\
.000\end{array}$ & $\begin{array}{r}.673^{* *} \\
.000\end{array}$ & 1 & & \\
\hline BVS & $\begin{array}{l}\text { Pearson Correlation } \\
\text { Sig. (2-tailed) }\end{array}$ & $\begin{array}{r}.621^{* *} \\
.000\end{array}$ & $\begin{array}{r}.622^{* *} \\
.000\end{array}$ & $\begin{array}{r}.607^{* * *} \\
.000\end{array}$ & $\begin{array}{r}.761^{* *} \\
.000\end{array}$ & $\begin{array}{r}.643^{* *} \\
.000\end{array}$ & 1 & \\
\hline CFS & $\begin{array}{l}\text { Pearson Correlation } \\
\text { Sig. (2-tailed) }\end{array}$ & $\begin{array}{r}-.010 \\
.920\end{array}$ & $\begin{array}{r}-.024 \\
.815\end{array}$ & $\begin{array}{r}-.016 \\
.873\end{array}$ & $\begin{array}{r}-.159 \\
.118\end{array}$ & $\begin{array}{r}-.011 \\
.915\end{array}$ & $\begin{array}{r}-.072 \\
.480\end{array}$ & 1 \\
\hline
\end{tabular}

**. Correlation is significant at the 0.01 level (2-tailed).

There was also significant positive and strong association between dividends and share values at 3 points ( $\mathrm{r}$ $=.662 ; \mathrm{r}=.661 ; \mathrm{r}=.660$ respectively). Table 3 also reflects a significant positive and strong association between book value and 3 share prices $(r=.621 ; r=.622 ; r=.607$ respectively). All the significant relationships above reflected $p<.0001$. The results signify that the rise in earnings, dividends or book value would result in an increase in each of the 3 share prices. However, Table 3 depicts an insignificant negative and weak association between cash flows and each of the 3 prices $(r=-.010 ; r=-.024$ and $r=-.016$ respectively) implying that operating cash flows and share prices were moving on opposite directions.

While still on Table 3, significant positive and strong relationships were observed between earnings and dividend and between earnings and book value per share $(\mathrm{r}=.673 ; \mathrm{r}=.761$ respectively). The cash flows per share displayed an insignificant negative and very weak association with earnings per share $(r=-.159)$. The association between dividends per share and book value per share was significant positive and strong $(r=.643)$ while that one between dividends and operating cash flows was insignificant negative and very weak $(\mathrm{r}=-.011)$. The association between cash flows and book value per share was also insignificant negative and very weak $(\mathrm{r}=$ $-.072)$.

\subsection{Regression}

Table 4 displays the results of the bivariate regression analysis of 12 models. Table 4 shows that the earnings per share was value relevant in respect of all 3 market prices with $\mathrm{R}^{2}$ of $55.3 \%$ at the end of the year, $57.7 \%$ at the end of 3 months after the year end and $60.9 \%$ at the end of 6 months after the year end with a significant F-statistic . 
Table 4. Bivariate regression analysis of market share price model and EPS, DVS, BVS, and CFS

\begin{tabular}{lllccccc}
\hline \multicolumn{1}{c}{ Model } & Variables & Beta & $\mathbf{t}$ & Sig. & $\mathbf{R}^{2}$ & $\mathbf{F}$ & Sig \\
\hline MSPjt & EPS & .743 & 10.893 & .000 & .553 & 118.654 & $.000^{b}$ \\
MSPjt & DVS & .662 & 8.666 & .000 & .439 & 75.093 & .000 \\
MSPjt & BVS & .621 & 7.754 & .000 & .385 & 60.129 & .000 \\
MSPjt & CFS & -.010 & -0.101 & .920 & .000 & .010 & .920 \\
& & & & & & & \\
MSPjt $_{+1 / 4}$ & EPS & .760 & 11.448 & .000 & .577 & 131.066 & .000 \\
MSPjt $_{+1 / 4}$ & DVS & .661 & 8.620 & .000 & .436 & 74.310 & .000 \\
MSPjt $_{+1 / 4}$ & BVS & .622 & 7.785 & .000 & .387 & 60.612 & .000 \\
MSPjt $_{+1 / 4}$ & CFS & -.024 & -.235 & .815 & .001 & .055 & .815 \\
MSPjt $_{+1 / 2}$ & EPS & .780 & 12.219 & .000 & .609 & 149.310 & .000 \\
MSPjt $_{+1 / 2}$ & DVS & .660 & 8.614 & .000 & .436 & 74.203 & .000 \\
MSPjt $_{+1 / 2}$ & BVS & .607 & 7.478 & .000 & .368 & 55.927 & .000 \\
MSPjt $_{+1 / 2}$ & CFS & -.016 & -.160 & .873 & .000 & .026 & .873 \\
\hline
\end{tabular}

These results tell us that the earnings in the Botswana market are most value relevant to the market share prices at the end of 6 months after the year end. Table 4 also reflects that the further we move from the year end, the more value relevant the earnings become to market share values as indicated by the rising $\mathrm{R}^{2}$ of earnings.

Table 4 also reports that dividends were relevant in predicting share prices at year end, at the end of 3 months after year end and at the end of 6 months after year end, with $\mathrm{R}^{2}$ of $43.9 \%, 43.6 \%$ and $43.6 \%$ respectively and all of them reflecting significant F-statistic. The value relevance of dividends displayed minimal fluctuations within period of 6 months as compared to earnings. Dividends' value relevance was lower than that of earnings. Book value also exhibited weak but significant value relevance to the share values at year end, at the end of 3 months after year end and at the end of 6 months after year end, with $\mathrm{R}^{2}$ of $38.5 \%, 38.7 \%$ and $36.8 \%$ respectively and significant F-statistic but with unstable trend.

Furthermore, the information in Table 4 demonstrates that operating cash flows were apparently not value relevant to share prices. Operating cash flows were associated with insignificant negative and very weak $\mathrm{R}^{2}$. In relation to share price at the end of the year $R^{2}$ is .000 , in relation to share price 3 months after the year end $\mathrm{R}^{2}$ is .001 and at the end of 6 months after the year end $\mathrm{R}^{2}$ is .000 . Table 4 also depicts earnings being more value relevant to share prices than book value and dividends.

It should be noted that dividends displayed a higher explanatory power of market share prices than book values. Therefore in ranking, earnings were the most value relevant, followed by dividends and book value being the last.

In summary, Table 4 shows that earnings, dividends and book value were all value relevant to market share prices at the end of the year, 3 months after the end of the year and 6 months after the end of the year. Therefore on the basis of individual analysis alternative hypotheses 1 to 9 about earnings, book value and dividends were all accepted but hypotheses 10 to 12 regarding cash flows were negated.

Table 5 reflects the results of multivariate regression analysis of market share prices at the end of the year, at the end of 3 months after the year end and at the end of 6 months after year end against the earnings, dividends, book value and operating cash flows per share. Market share value model at the end of the accounting period yielded $\mathrm{R}^{2}$ of $60.8 \%$ with a statistically significant $\mathrm{F}$-test $(F=36.06, P<.001)$ 
Table 5. Multivariate regression analysis of MSPjt, MSPjt $+_{+1 / 4}$ and MSPjt $t_{+1 / 2}$ Models

\begin{tabular}{|c|c|c|c|c|c|c|c|c|}
\hline \multirow[b]{2}{*}{ Model } & \multirow[b]{2}{*}{ Variables } & \multicolumn{2}{|c|}{$\begin{array}{l}\text { Unstandardized } \\
\text { Coefficients }\end{array}$} & \multicolumn{2}{|l|}{$\begin{array}{l}\text { Standardized } \\
\text { Coefficients }\end{array}$} & \multirow[b]{2}{*}{ Sig. } & \multicolumn{2}{|c|}{ Collinearity Statistics } \\
\hline & & $\mathrm{B}$ & Std. Error & Beta & $\mathrm{t}$ & & Tolerance & VIF \\
\hline \multicolumn{9}{|l|}{ MSPjt } \\
\hline & (Constant) & 87.457 & 62.468 & & 1.400 & .168 & & \\
\hline & EPS & 6.870 & 1.382 & .546 & 4.972 & .000 & .350 & 2.859 \\
\hline & DVS & 4.267 & 1.430 & .274 & 2.983 & .004 & .500 & 2.000 \\
\hline & BVS & .088 & .265 & .035 & .333 & .740 & .388 & 2.576 \\
\hline & CFS & .252 & .204 & .082 & 1.236 & .220 & .956 & 1.046 \\
\hline & \multicolumn{8}{|c|}{$\mathrm{R}^{2}=.608 ;$ Adjusted $\mathrm{R}^{2}=.591 ; \mathrm{F}=36.060$, Sig. $=0.000^{\mathrm{b}}$} \\
\hline \multirow{6}{*}{$\mathrm{MSPjt}_{+1 / 4}$} & (Constant) & 93.017 & 62.171 & & 1.496 & .138 & & \\
\hline & EPS & 7.504 & 1.375 & .587 & 5.457 & .000 & .350 & 2.859 \\
\hline & DVS & 4.057 & 1.424 & .257 & 2.850 & .005 & .500 & 2.000 \\
\hline & BVS & .039 & .264 & .015 & .150 & .881 & .388 & 2.576 \\
\hline & CFS & .228 & .203 & .073 & 1.127 & .263 & .956 & 1.046 \\
\hline & \multicolumn{8}{|c|}{$\mathrm{R}^{2}=.623 ;$ Adjusted $\mathrm{R}^{2}=.607 ; \mathrm{F}=38.4760$, Sig. $=0.000^{\mathrm{b}}$} \\
\hline \multirow[t]{6}{*}{ MSPjt $_{+1 / 2}$} & (Constant) & 81.597 & 62.306 & & 1.310 & .194 & & \\
\hline & EPS & 8.944 & 1.378 & .672 & 6.490 & .000 & .350 & 2.859 \\
\hline & DVS & 4.040 & 1.427 & .245 & 2.831 & .006 & .500 & 2.000 \\
\hline & BVS & -.152 & .264 & -.057 & -.576 & .566 & .388 & 2.576 \\
\hline & CFS & .289 & .203 & .089 & 1.423 & .158 & .956 & 1.046 \\
\hline & \multicolumn{8}{|c|}{$\mathrm{R}^{2}=.651 ;$ Adjusted $\mathrm{R}^{2}=.636 ; \mathrm{F}=43.330$, Sig. $=0.000^{\mathrm{b}}$} \\
\hline
\end{tabular}

This tells us that almost $61 \%$ of variations in the market share price are influenced by a combination of earnings, dividends, book value and cash flows. However, only the combination of earnings and dividends made a positive and significant contribution to changes in share prices. Book value and cash flows displayed insignificant beta statistic.

The market share price model at the end of 3 months after the year end also produced a high $\mathrm{R}^{2}$ of $62.3 \%$ ( $F=$ $38.48, P<.001)$ providing the evidence of value relevance of a combination of earnings, dividends, book value and cash flows. Like in the end of year model, only earnings and dividends appeared to be relevant with statistically significant beta coefficients of $58.7 \%$ and $25.7 \%$ respectively in the 3 months after year end model. Book value and cash flows were irrelevant to market share price at end of 3 months as evidenced by statistically insignificant beta statistic. The 3 months after year end model produced higher value relevance $\left(R^{2}=62.3 \%\right)$ than the end of year model $\left(R^{2}=60.8 \%\right)$.

Table 5 further displays the share price at the end of 6 months after the year end model having the highest $\mathrm{R}^{2}$ of $65.1 \%$ ( $F=43.33, P<.001$ ) implying superior value relevance of a combination of earnings, dividends, book value and cash flows. In this model earnings per share appear to be the highest contributor to the fluctuations in the share price with the highest statistically significant beta coefficient of $67.2 \%$ followed by dividend per share with beta coefficient of $24.5 \%$. Book value and cash flows are again irrelevant to share prices in this model with insignificant beta coefficient of $-5.7 \%$ and $8.9 \%$ respectively.

\section{Discussion}

The results of this study provide support of the strong associations between earnings and share prices; between dividends and share prices and between book value and share prices but give evidence of weak relationship between operating cash flows and share prices. Moreover, the association between accounting information and share prices was the strongest at the end of 6th month after the year end. In addition, the results indicate that earnings had the strongest association with prices while book value had the least relationship among the 3 accounting amounts which happened to have significant association with prices. Operating cash flows had a very weak association with share prices. These findings, to a greater extent, support findings of Busari and Bagudo (2018) who reported earnings having the strongest association with prices, followed by book value and then dividends and cash flows. In this study dividends were the second strongest in the association with prices. Badu and Appiah (2018) also reported a higher association between earnings and share prices than between book value and share prices. On the contrary, in the work by Enofe, Asiriuwa and Ashafoke (2014) book value's association with share price was superior to that of earnings. Kwon (2009) also did not find an association between earnings per share and share price.

The analysis of the explanatory power of earnings, dividends and book value individually indicated that each 
accounting amount is value relevant to all 3 share prices examined by this study. This is consistent with prior studies which established value relevance of these amounts. See for example, Barth, Li and McClure (2018), Elshandidy (2014), Ali and Hwang (2000) and Che (2007). The results of this study suggest that the value relevance of earnings, dividend and book value was strongest to market share price at the end of 6th month after year end compared to the end of year or end of 3 months after year end prices. These results are however contrary to the findings of Jabar (2012) who reported that annual closing share price was more reliable in detecting the value relevance of accounting information in Turkish market as compared to prices at end of 3 months after year end.

Contrary to prior studies, such as Kwon (2009) and Olugbenga and Atanda (2014) who reported a significant explanatory power of operating cash flows, this study found cash flows to be irrelevant information for the market share prices in Botswana. However, the results support the findings of Busari and Bagudo (2018) who also found insignificant effect of cash flows on market share prices in Nigerian financial institutions.

The supremacy of value relevance of earnings over dividends, book value and cash flows was also demonstrated by this study. These results are consistent with the findings of Badu and Appiah (2018) who also established that the earnings explained higher fluctuations in share prices than book value in Ghana market. Results of this study also are consistent with those of Ernest and Oscar (2014) who established that earnings per share had the highest value relevance compared to that of book value and leverage per share. However, the findings do not concur with results of Akeem Adetunji (2016) and Okafor and Odia (2011) who found earnings to be irrelevant in predicting share prices of companies in banking sector in Nigeria.

Furthermore, this study established the superiority of value relevance of combined earnings and dividends over that one of combined earnings and book values which has been prominent in the prior studies (Kwon, 2009; Elshandidy, 2014). In the Botswana equity market the reporting of earnings and dividends appeared to attract the investors more. This could be due to the fact that the two sets of information are easily understood by market players as they are normally reported in a form that does not require further manipulation of figures.

Contrary to the results of Jabar (2012) which documented price at the end of the year being more reflective of shareholders consideration of accounting information, this study's results showed the price at the end of 6 months from the year end capturing investors' share valuation more than prices at end of year and at end of 3 months after year end. This suggests that investors in Botswana stock market incorporate the reported information into share prices much later in the year, implying that they trust more information released than information anticipated.

This study has answered its two key questions it intended to provide responses to. The findings of this study provide evidence that earnings per share are the most predictive information of the share prices in the Botswana stock exchange. Moreover, the market share price at the end of 6 months after year end is the most reflective price of the investors' consideration of the accounting information produced by companies listed on the Botswana capital markets.

The results of this study have implications on research as they open up more research avenues in developing countries with less sophisticated capital markets. The value relevance of book value and operating cash flows to market share prices in developing countries still need to be examined further before a general position can be established. A negative and weak association between earnings and operating cash flow depicted by this study could be suggesting the existence of excessive accruals in the accounts which may imply earnings management (Velte, 2017). This is an area which requires further investigation.

The findings of this research also have implications on investors as they suggest that participants in the BSE consider information disseminated through the income statement and statement on changes in equity more than the information released through statements of cash flows and statement of financial position in determining the share prices. Implications to Accounting standards-setters can also be deduced from this study. Accounting standards-setters, for example BAOA in Botswana, need to maintain continuous review of standards to ensure that listed firms produce financial statements which contain more useful information to investors. The BSE should also continue pursuing sterner compliance to reporting regulations.

\section{Conclusion and Recommendations}

This paper set out to examine the statistical association between earnings, book value, dividends and operating cash flows per share with market share prices at 3 different dates. Another objective was to determine which market share price mostly reflects investors' consideration of accounting information. In agreement with prior studies the current study results suggest that earnings per share have the highest value relevance to all the 3 
prices, at the end of the year, at 3 months after the year end and at 6 months after the year end. Dividends follow in the second place of relevance and book value becomes the last in triggering fluctuations in market share prices in the BSE.

Although earnings and book value had the strongest positive association among the independent variables, it is only the combination of dividends and earnings which significantly contributed to the variations in share prices. Book value and cash flows were irrelevant in predicting the share prices in Botswana capital market. The results of this study also show that the most affected market share value by the earnings and dividend per share is the one at the end of 6 months after the year end. Since companies quoted in BSE are required to release the abridged audit financial statements within 3 months of their production, the results of this study signify that shareholders in Botswana market are more likely to wait for the actual publication of the information about earnings and dividends before they can incorporate it in the share valuation.

The value relevance of cash flows has been suggested by a good number of prior studies with some proposing that value relevance of cash flows could be replacing that of earnings. However, the findings of this study could not support this view. Therefore, further studies may be conducted to compare the value relevance of earnings and cash flows in companies with negative operating cash flows and those with positive cash flows. In the current study that distinction was not made. Other studies may attempt to investigate the value relevance of accounting amounts by using the net cash flows generated from all sources to establish whether shareholders consider such information in determining market share prices. Subsequent studies may also be conducted in Botswana to assess whether value relevance of accounting information is growing or declining given technological developments which have the potential of improving financial information quality.

\section{References}

Agostino, M., Drago, D., \& Silipo, D. B. (2011). The value relevance of IFRS in the European banking industry. Review of quantitative finance and accounting, 36(3), 437-457. https://doi.org/10.1007/s11156-010-0184-1

Akeem, A. S. (2016). The value relevance of earnings in the return-earnings relation in the Nigerian Deposit Money Banks. Cogent Business \& Management, 3(1), 1210276. https://doi.org/10.1080/23311975.2016.1210276

Alexander, D., Britton, A., \& Jorissen, A. (2007).International Financial Reporting Analysis (3rd ed.). Thomson Learning, London.

Ali, A., \& Hwang, L. S. (2000). Country-specific factors related to financial reporting and the value relevance of accounting data. Journal of accounting research, 38(1), 1-21. https://doi.org/10.2307/2672920

Baboukardos, D., \& Rimmel, G. (2016). Value relevance of accounting information under an integrated reporting approach: A research note. Journal of Accounting and Public Policy, 35(4), 437-452. https://doi.org/10.1016/j.jaccpubpol.2016.04.004

Badu, B., \& Appiah, K. (2018). Value relevance of accounting information: an emerging country perspective. Journal of Accounting \& Organizational Change, 14(4), 473-491. https://doi.org/10.1108/JAOC-07-2017-0064

Ball, R., \& Brown, P. (1968). An empirical evaluation of accounting income numbers. Journal of accounting research, 159-178. https://doi.org/10.2307/2490232

Ball, R., \& Brown, P. R. (2014). Ball and Brown (1968): A retrospective. The Accounting Review, 89(1), 1-26. https://doi.org/10.2308/accr-50604

Barth, M. E. (2000). Valuation-based accounting research: Implications for financial reporting and opportunities for future research. Accounting \& Finance, 40(1), 7-32. https://doi.org/10.1111/1467-629X.00033

Barth, M. E., Beaver, W. H., \& Landsman, W. R. (2001). The relevance of the value relevance literature for financial accounting standard setting: another view. Journal of accounting and economics, 31(1-3), 77-104. https://doi.org/10.1016/S0165-4101(01)00019-2

Barth, M. E., Li, K., \& McClure, C. (2018). Evolution in value relevance of accounting information. Retrieved from https://www.gsb.stanford.edu/faculty-research/working-papers/evolution-value-relevance-accounting-infor mation. https://doi.org/10.2139/ssrn.2933197

Botswana Stock Exchange. (2018). Equity Listings Requirements Version 3.2, Botswana Stock Exchange, Gaborone. Retrieved from 
https://www.bse.co.bw/docs/BSE_Equity_Listings_Requirements_NBFIRA_Approved.pdf

Botswana Stock Exchange. (n.d). Role in Botswana. Retrieved from https://www.bse.co.bw/abt_us/role_in_botswana.php

BrainMass. (n.d). Relevance $v$ Relaibility. Retrieved from https://brainmass.com/business/relevance-reliability

Busari, K., \& Bagudo, M. M. (2018). Comparative Value Relevance of Accounting Information for Consolidated and Separate Financial Statements of Listed Financial Service Firms in Nigeria. SSRN 3277485. Retrieved from https://doi.org/10.2139/ssrn.3277485

Che, B. (2007). Value-relevance of accounting information and shareholding structure in emerging capital markets: evidence from Chinese listed companies (Doctoral dissertation). Newcastle University, Newcastle, UK.

de Klerk, M., \& de Villiers, C. (2012). The value relevance of corporate responsibility reporting: South African evidence. Meditari Accountancy Research. https://doi.org/10.1108/10222521211234200

Elshandidy, T. (2014). Value relevance of accounting information: Evidence from an emerging market. Advances in Accounting, 30(1), 176-186. https://doi.org/10.1016/j.adiac.2014.03.007

Enofe, A. O., Asiriuwa, O., \& Ashafoke, T. O. (2014). Value relevance of accounting information in the banking subsector of the Nigeria stock exchange (NSE). British Journal of Accounting, Auditing and Finance Research, 1(1), 42-55.

Ernest, O., \& Oscar, M. C. (2014). The comparative study of value relevance of financial information in the Nigeria banking and petroleum sectors. Journal of Business Studies Quarterly, 6(1), 42.

Financial Accounting Standards Board. (2010). Conceptual Framework for Financial Reporting: Statement of Financial Reporting Concepts No. 8. Retrieved from https://www.fasb.org/jsp/FASB/Document_C/DocumentPage?cid=1176157498129\&acceptedDisclaimer=tr ue

Hodgson, A., \& Stevenson-Clarke, P. (2000). Earnings, cash flows and returns: Functional relations and the impact of firm size. Accounting \& Finance, 40(1), 51-74. https://doi.org/10.1111/1467-629X.00035

Holthausen, R. W., \& Watts, R. L. (2001). The relevance of the value-relevance literature for financial accounting standard setting. Journal of accounting and economics, 31(1-3), 3-75. https://doi.org/10.1016/S0165-4101(01)00029-5

International Accounting Standards Board. (2018). Conceptual Framework for Financial Reporting. London, United Kingdom.

Jabar, D. S. (2012). The Influence of Institutional Factors on the Value Relevance of Accounting Information: Evidence from Jordan (Doctoral dissertation). Universiti Utara, Kedah Darul Aman, Malaysia.

Karğın, S. (2013). The impact of IFRS on the value relevance of accounting information: Evidence from Turkish firms. International Journal of Economics and Finance, 5(4), 71-80. https://doi.org/10.5539/ijef.v5n4p71

Kumari, P., \& Mishra, C. S. (2017). A Literature Review of Ohlson (1995). Asian Journal of Finance and Accounting, 9(2), 1-20. https://doi.org/10.5296/ajfa.v9i2.11492

Kwon, G. J. (2009). The value relevance of book values, earnings and cash flows: Evidence from South Korea. International Journal of Business and Management, 4(10), 28-42. https://doi.org/10.5539/ijbm.v4n10p28

Ohlson, J. (1995). Earnings, book values and dividends in equity valuation. Contemporary Accounting Research, 11(2), 661-687. https://doi.org/10.1111/j.1911-3846.1995.tb00461.x

Okafor, C. A., \& Odia, J. (2011). Value Relevance of Accounting Information in the Nigerian Banking Sector. Adsu Journal of Accounting Research, Journal of the Department of Accountancy, Adamawa State University, Mubi., l(1), 104-113.

Olowolaju, P. S., \& Ogunsan, J. O. (2016) Value relevance of accounting information in the determination of shares prices of quoted Nigerian deposit money banks. International Journal of Economics, Commerce and Management, 4(10), 128-147.

Olugbenga, A. A., \& Atanda, O. A. (2014). Value relevance of financial accounting information of quoted companies in Nigeria: A trend analysis. Research Journal of Finance and Accounting, 5(8), 86-93.

Sami, H., \& Zhou, H. (2004). A comparison of value relevance of accounting information in different segments 
of the Chinese stock market. The International Journal of Accounting, 39(4), 403-427. https://doi.org/10.1016/j.intacc.2004.08.001

Umoren, A. O., Akpan, P. W., \& Ekeria, E. V. (2018). Value Relevance of Accounting Information in Nigerian Listed Financial Companies. Advances in Research, 1-8. https://doi.org/10.9734/AIR/2018/42794

Uwuigbe, O. R., Uwuigbe, U., Jafaru, J., Igbinoba, E. E., Oladipo, O., \& Oni-Ojo, E. E. (2016). Value relevance of financial statements and share price: a study of listed banks in Nigeria. Banks and Bank Systems, 11(4), 135-143. https://doi.org/10.21511/bbs.11(4-1).2016.04

Velte, P. (2017). What do we know about empirical joint audit research? A literature review. Accounting and Financial Control, 1(1). https://doi.org/10.21511/afc.01(1).2017.01

Venter, E. R., Emanuel, D., \& Cahan, S. F. (2014). The value relevance of mandatory non-GAAP earnings. Abacus, 50(1), 1-24. https://doi.org/10.1111/abac.12020

\section{Copyrights}

Copyright for this article is retained by the author(s), with first publication rights granted to the journal.

This is an open-access article distributed under the terms and conditions of the Creative Commons Attribution license (http://creativecommons.org/licenses/by/4.0/). 